\title{
Degradation rates of alachlor, atrazine and bentazone in the profiles of Polish Luvisols
}

\author{
Tadeusz Paszko* and Pawet Muszyński \\ Department of Chemistry, University of Life Sciences in Lublin, Akademicka 13, 20-950 Lublin, Poland \\ Received September 29, 2016; accepted April 27, 2017
}

\begin{abstract}
A b s t r a c t. The degradation rates of three herbicides (alachlor, atrazine, and bentazone) were examined according to OECD Guideline 307 in three profiles of grey-brown podzolic soil (Luvisol) in a laboratory experiment. The aim of the experiment was to determine herbicide degradation parameters and their relationships with soil properties. Degradation processes were effectively described by a first-order model. However, in some cases, the best results were produced by bi-phasic kinetics (hockey-stick and bi-exponential model). The degradation rates of the tested herbicides at $25^{\circ} \mathrm{C}$ and $40 \%$ maximum water holding capacity, established based on half-life values in the Ap horizon, increased in the following order: atrazine (32.6-42.8 days) $<$ bentazone (3.4-16.6 days $<$ alachlor (4.4-5.7 days). The correlation analysis and the Principal Component Analysis revealed significant positive correlations between the herbicide degradation rates and the organic matter content of soils. The depth-dependent degradation factors obtained for topsoil and two subsoil horizons (1: 0.42: 0.11 - based on average values, and 1: 0.31: 0.12 - based on median values) reflect the degradation abilities of Polish Luvisols. The values noted are soil-specific; therefore, they can also be applied to other pesticides in Polish Luvisols.

K e y w o r d s: herbicide, degradation, soil horizons, depthdependent degradation factor
\end{abstract}

\section{INTRODUCTION}

Pesticides introduced into soil undergo various physical, chemical, and biological transformations, including concurrent sorption, degradation, and translocation along the soil profile. Numerous attempts have been made to correlate sorption and degradation processes with soil parameters (Ghafoor et al., 2011a; Norgaard et al., 2015; Vinther et al., 2008). The organic matter content and the biomass of soil microorganisms decrease with an increase

*Corresponding author e-mail: tadeusz.paszko@up.lublin.pl in profile depth; therefore, pesticide degradation in subsoils is slower (Goberna et al., 2006). However, in some cases, the degradation rate may increase deeper into the soil profile (Karpouzas et al., 2001), for example, when the decrease in the organic matter content in subsoils is accompanied by an increase in the bioavailability of the pesticide (Di et al., 1998). The activity of soil enzymes and the overall biological activity of soil are usually well correlated with pesticide degradation rates in topsoil. However, this correlation is much weaker in subsoils. The degradation rate in soil horizons with a depth of around $1 \mathrm{~m}$ is often lower than that estimated based on biomass content and other indicators of microbial activity, including organic matter content (Paszko, 2009; Rodríguez-Cruz et al., 2008). Therefore, the best method so far is the direct determination of degradation rates in individual soil horizons.

This study describes the degradation rates of three herbicides - alachlor (2-chloro-2', 6'-diethyl-N-methoxymethylacetanilide), bentazone (3-isopropyl-1H-2,1,3benzothiadiazin-4(3H)-one 2,2-dioxide), and atrazine (6-chloro- $\mathrm{N}^{2}$-ethyl- $\mathrm{N}^{4}$-isopropyl-1,3,5-triazine-2,4-diamine) - in three profiles of Polish Luvisols. Alachlor is a chloroacetanilide herbicide for controlling annual grasses and broadleaf weeds, primarily in the cultivation of maize, soybeans, peanuts, cotton, and cabbage. It undergoes weak sorption in soil (organic carbon normalized adsorption coefficient $\mathrm{K}_{\mathrm{OC}}=33-742 \mathrm{~cm}^{3} \mathrm{~g}^{-1}$, Wauchope et al., 1992) and can leach to surface water and groundwater (Spalding et al., 2003; Vryzas et al., 2012). Alachlor can undergo chemical decomposition (Chou, 1977) and photodegradation in soil (Fang, 1979), but microbial degradation $\left(\mathrm{DT}_{50}=8-17 \mathrm{~d}, \mathrm{DT}_{50}\right.$

(C) 2017 Institute of Agrophysics, Polish Academy of Sciences 
- 50\% disappearance time) (Tomlin, 2006) has the greatest practical relevance (Dehghani et al., 2013). Bentazone is a benzothiadiazine herbicide for controlling dicotyledonous weeds. It is weakly adsorbed in soil $\left(\mathrm{K}_{\mathrm{OC}}=13.3-176 \mathrm{~cm}^{3}\right.$ $\mathrm{g}^{-1}$, Tomlin, 2006), and it is decomposed mainly by microorganisms (Blume et al., 2004; Li et al., 2008), although photolytic degradation has also been reported (Huber and Otto, 1994). This compound has a $\mathrm{DT}_{50}$ value of around 4-21 d in field conditions and 8-102 d in laboratory conditions (PPDB, 2016). Atrazine is a triazine herbicide that is commonly used to protect maize and soybeans. Atrazine adsorption in soil is relatively weak $\left(\mathrm{K}_{\mathrm{OC}}=39-173 \mathrm{~cm}^{3} \mathrm{~g}^{-1}\right)$, and it is degraded mainly by microorganisms ( $\mathrm{Li}$ et al., $2008)$ at a slow rate $\left(\mathrm{DT}_{50}=16-77 \mathrm{~d}\right.$, median $41 \mathrm{~d}$ (Tomlin, 2006)). Atrazine and alachlor are highly toxic for the environment, and they are not approved for use in the European Union (EU pesticide database, 2016). However, both herbicides are used in other countries, including the USA (NPIC, 2016).

In programs modelling the translocation of active substances into groundwater, which are recommended by FOCUS (2014) and mandatory in the pesticide registration process in the EU, the half-life values of pesticides should be specified for topsoil as well as the values of the depth-dependent degradation factor (DDDF) for subsoils. The DDDF value describes the difference between the degradation rates in the examined horizon and topsoil. Previous research (Paszko, 2009; 2014) has demonstrated that DDDF values for the coarsest Polish soils developed on sands (Arenosols according to the IUSS Working Group WRB, 2015) are lower than the default values proposed in FOCUS programs. These findings also suggest that DDDF values could be lower for Luvisols, which account for around $50 \%$ of agricultural soils in Poland (Bieganowski et al., 2013). The prevalent soil types in Poland are coarser or have lower organic carbon content (European Commission, 2014), which implies that some active substances that have been approved for use in the EU should not be applied in Poland due to the risk of exceeding the allowable concentrations in groundwater.

The aim of this study was to determine the $\mathrm{DT}_{50}$ and DDDF values of alachlor, atrazine, and bentazone in horizons of three Polish Luvisol profiles. Herbicide degradation parameters were correlated with the physicochemical properties of soil, and the nature of the determined DDDF values was evaluated.

\section{MATERIALS AND METHODS}

Three profiles (Fig. 1) of grey-brown podzolic soils (Luvisols, according to the IUSS Working Group WRB2015) were analysed as the predominant agricultural soils in Poland with different physicochemical properties (Table 1), based on the information supplied by the Institute of Soil Sciences and Environment Shaping of the University of Life Sciences in Lublin and the Institute of Agrophysics of the Polish Academy of Science in Lublin. The examined soil samples were collected in Huta Turobińska (HT) $\left(22^{\circ} 69^{\prime} \mathrm{N}\right.$, $\left.50^{\circ} 80^{\prime} \mathrm{E}\right)$, Wola Osińska (WO) $\left(22^{\circ} 10^{\prime} \mathrm{N}, 51^{\circ} 46^{\prime} \mathrm{E}\right)$ and

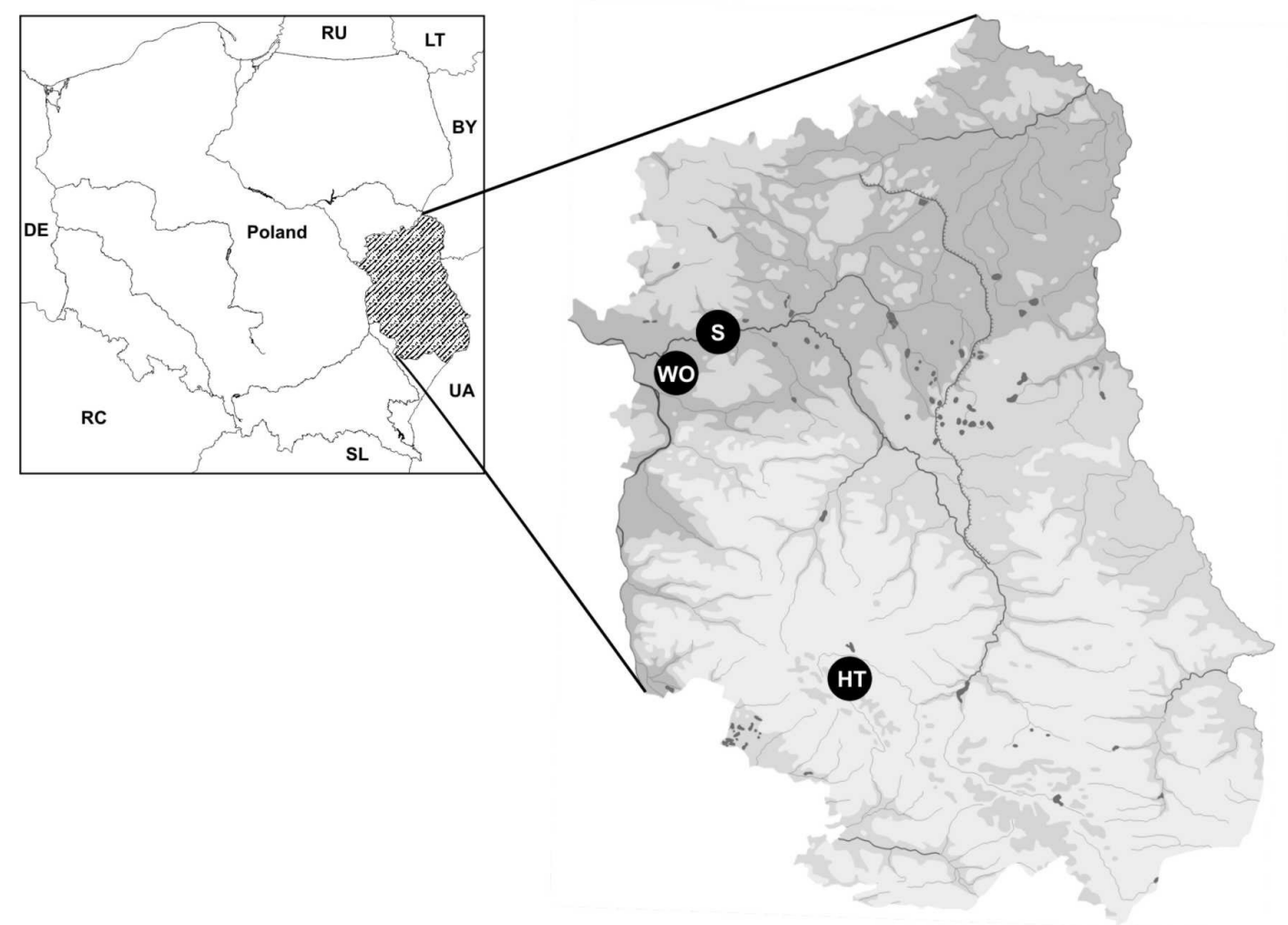

Fig. 1. Location of soil profiles on the map of Poland ( $\mathrm{S}$ - Sobieszyn, WO - Wola Osińska, HT - Huta Turobińska). 
T a b l e 1. Physical and chemical properties of soils

\begin{tabular}{|c|c|c|c|c|c|c|c|c|c|}
\hline \multirow{2}{*}{$\begin{array}{l}\text { Soil property } \\
\text { Horizon }\end{array}$} & \multicolumn{3}{|c|}{ Huta Turobińska (HT) } & \multicolumn{3}{|c|}{ Wola Osińska (WO) } & \multicolumn{3}{|c|}{ Sobieszyn (SO) } \\
\hline & Ap & $\mathrm{E}$ & $\mathrm{Bt}$ & Ap & Bt1 & $\mathrm{Bt} 2$ & Ap & Bt1 & Bt2 \\
\hline Sampling depth $(\mathrm{cm})$ & $5-15$ & $25-35$ & $75-90$ & $5-20$ & $30-50$ & $70-80$ & $5-15$ & $30-40$ & $55-60$ \\
\hline Textural group (USDA) & $\mathrm{Si}$ & SiL & $\mathrm{SiL}$ & $\mathrm{SL}$ & $\mathrm{CL}$ & $\mathrm{C}$ & SL & $\mathrm{L}$ & $\mathrm{CL}$ \\
\hline $\mathrm{C}_{\text {sand }}(\%)$ & 15 & 22 & 12 & 60 & 41 & 24 & 53 & 46 & 39 \\
\hline $\mathrm{C}_{\text {silt }}(\%)$ & 80 & 76 & 71 & 35 & 31 & 30 & 42 & 31 & 32 \\
\hline $\mathrm{C}_{\text {clay }}(\%)$ & 5 & 2 & 17 & 5 & 28 & 46 & 5 & 23 & 29 \\
\hline $\mathrm{C}_{\mathrm{OC}}(\%)$ & 0.76 & 0.50 & 0.07 & 0.75 & 0.26 & 0.12 & 0.80 & 0.28 & 0.10 \\
\hline $\mathrm{pH}\left(0.01 \mathrm{M} \mathrm{CaCl}_{2}\right)$ & 6.1 & 5.4 & 4.7 & 5.4 & 4.7 & 4.4 & 6.7 & 6.2 & 6.4 \\
\hline MWHC (\%) & 35.4 & 35.2 & 35.1 & 30.3 & 39.5 & 45.0 & 30.8 & 35.5 & 44.7 \\
\hline
\end{tabular}

$\mathrm{C}_{\text {sand }}, \mathrm{C}_{\text {silt }}, \mathrm{C}_{\text {clay }}, \mathrm{C}_{\mathrm{OC}},-$ percentage content of sand, silt, clay and organic carbon in soil, respectively. MWHC - maximum water holding capacity.

Sobieszyn (SO) $\left(22^{\circ} 17^{\prime} \mathrm{N}, 51^{\circ} 60^{\prime} \mathrm{E}\right)$. The methods of soil analysis have been described elsewhere (Paszko, 2014). Soil samples were collected in autumn after the harvest of cereals fertilized with up to $75-30-40 \mathrm{~kg}$ of NPK ha ${ }^{-1}$ in the growing season and application of active substances of the plant protection products $0.3-0.7 \mathrm{~kg} \mathrm{ha}^{-1}$. Residues of the examined herbicides were not determined in any of the examined blank samples. Sampling depth was not based on diagnostic criteria for the examined horizons, but on expected changes in microbial activity based on FOCUS (2014) recommendations. Soil samples were collected carefully to prevent contamination from other horizons. They were passed through a $2 \mathrm{~mm}$ sieve, adjusted to $40 \%$ maximum water holding capacity (MWHC), and stored in the dark at $5^{\circ} \mathrm{C}$. The soil samples were collected not earlier than 1 month before the beginning of the experiments.

Methanol solutions of the tested herbicides at a concentration of $100 \mathrm{mg} \mathrm{l}^{-1}$ each were prepared using analytical grade methanol ( $\mathrm{POCH}$, Gliwice, Poland) and certified analytical standards $(99.7-99.8 \% \pm 0.2)$ of alachlor, bentazone, or atrazine (Institute of Organic Industrial Chemistry, Warsaw, Poland). The other chemicals were of analytical or HPLC grade.

Herbicide degradation experiments were performed in darkness at 25 and at $5^{\circ} \mathrm{C}$ for the Ap horizon according to OECD Guideline 307 (OECD, 2002). Soil samples stored at $5^{\circ} \mathrm{C}$ and intended for degradation at $25^{\circ} \mathrm{C}$ were preincubated at $25^{\circ} \mathrm{C}$ for 5 days. Next, soil samples with dry weight of $15 \mathrm{~g}$ each were placed in incubation flasks and spiked with the respective herbicide methanol solutions. The solvent was evaporated, soil was added to obtain samples with dry weight of $50 \mathrm{~g}$ each, and the contents of each flask were thoroughly mixed. The final concentrations of alachlor, atrazine, and bentazone (5.0, 5.0, and $2.5 \mathrm{mg} \mathrm{kg}^{-1}$ soil dry weight, respectively) were established based on the maximum herbicide doses permitted in Poland. Finally, water content was adjusted with sterile redistilled water to $40 \%$ MWHC. This step was repeated once a week. On days $0,2-4,7-8,14-15,21-22,29-30,60-61,89-90$, and 120-128 (depending on the analysed herbicide), soil samples with dry weight of $5 \mathrm{~g}$ each were collected from the incubation flasks and placed in $30 \mathrm{~cm}^{3}$ polypropylene tubes. Next, $5 \mathrm{~cm}^{3}$ of the methanol: $0.1 \mathrm{M} \mathrm{NaOH}$ solution (alachlor and bentazone) or $10 \mathrm{~cm}^{3}$ of methanol (atrazine) was injected; the tubes were agitated on a rotary shaker for $2 \mathrm{~h}$ and centrifuged (10 $\mathrm{min}, 2790 \mathrm{~g}$ ) to separate the liquid phase for analysis. The recoveries were in the range of $70-100 \%$. All degradation experiments were performed using duplicate soil samples.

A $20 \mu \mathrm{l}$ portion of the herbicide solution was injected into a WellChrom (Knauer, Berlin, Germany) HPLC system equipped with two K-500 pumps, a K-2500 UV-VIS detector and a Hypersil Gold $\mathrm{C}_{18}$ column $(100 \times 3.0 \mathrm{~mm}$, $3 \mu \mathrm{m}$ particle size, Thermo Electron Corporation, Runcorn, United Kingdom) preceded by a Hypersil Gold $\mathrm{C}_{18}$ guard column $(10 \times 3.0 \mathrm{~mm}, 3 \mu \mathrm{m}$ particle size $)$. The mobile phase was $40 \%$ acetonitrile for atrazine, $55 \%$ acetonitrile for alachlor, and acetonitrile $/ 0.25 \% \mathrm{H}_{3} \mathrm{PO}_{4}(64: 36 \mathrm{v} / \mathrm{v})$ for bentazone. The flow rate of the mobile phase was $0.7 \mathrm{~cm}^{3}$ $\min ^{-1}$ with a run time of 4-6 min per sample. The detection wavelength was $202 \mathrm{~nm}$ for alachlor and bentazone, and $222 \mathrm{~nm}$ for atrazine. All measurements were performed at least in duplicate.

The results of the degradation experiments were fitted to a first-order kinetic model, three bi-phasic kinetic models (Gustafson and Holden, hockey-stick and bi-exponential models (the latter abbreviated as Double-First-Order in Parallel model, DFOP)) and one lag-phase model (modified hockey-stick model). The models are described in detail in FOCUS (2006). The fitting procedure based on 
the Residual Sum of Squares (RSS), Chi-square test error $\left(\chi_{\text {error }}^{2}\right)$ (FOCUS 2006), and the values of the adjusted coefficient of multiple determination $\left(\mathrm{r}_{\mathrm{a}}^{2}\right)$ as well as determination of activation energy $\left(E_{a}\right)$ from the Arrhenius equation have been previously described by Paszko (2009) and Paszko (2014).

Data were processed statistically in the Statgraphics Centurion XVI program. Both Pearson $(r)$ and Spearman rank $\left(\rho_{\mathrm{S}}\right)$ correlation coefficients were used because Pearson $r$ is a measure of linear relationships, whereas $\rho_{\mathrm{S}}$ measures both linear and nonlinear correlations and is less sensitive to outliers. A principal component analysis (PCA) was performed to account for the collinearity between soil properties and degradation rates.

\section{RESULTS AND DISCUSSION}

The results of the degradation experiments and the fitted chemical kinetics equations are presented in Fig. 2. In most cases, the first-order kinetic model provided the best results (lowest RSS and $\chi_{\text {error }}^{2}$ and highest $r_{a}^{2}$ values). This model assumes that the number of pesticide molecules is small relative to the number of degrading microorganisms and their enzymes, and, consequently, that the degradation rate at any time is directly proportional to the actual concentration remaining in the system (FOCUS, 2006). The first-order kinetic model is generally regarded as indicative of cometabolic degradation, where the process does not result in the proliferation of degrading organisms (Rodríguez-Cruz et al., 2008; Schmidt et al., 1985). In some circumstances,
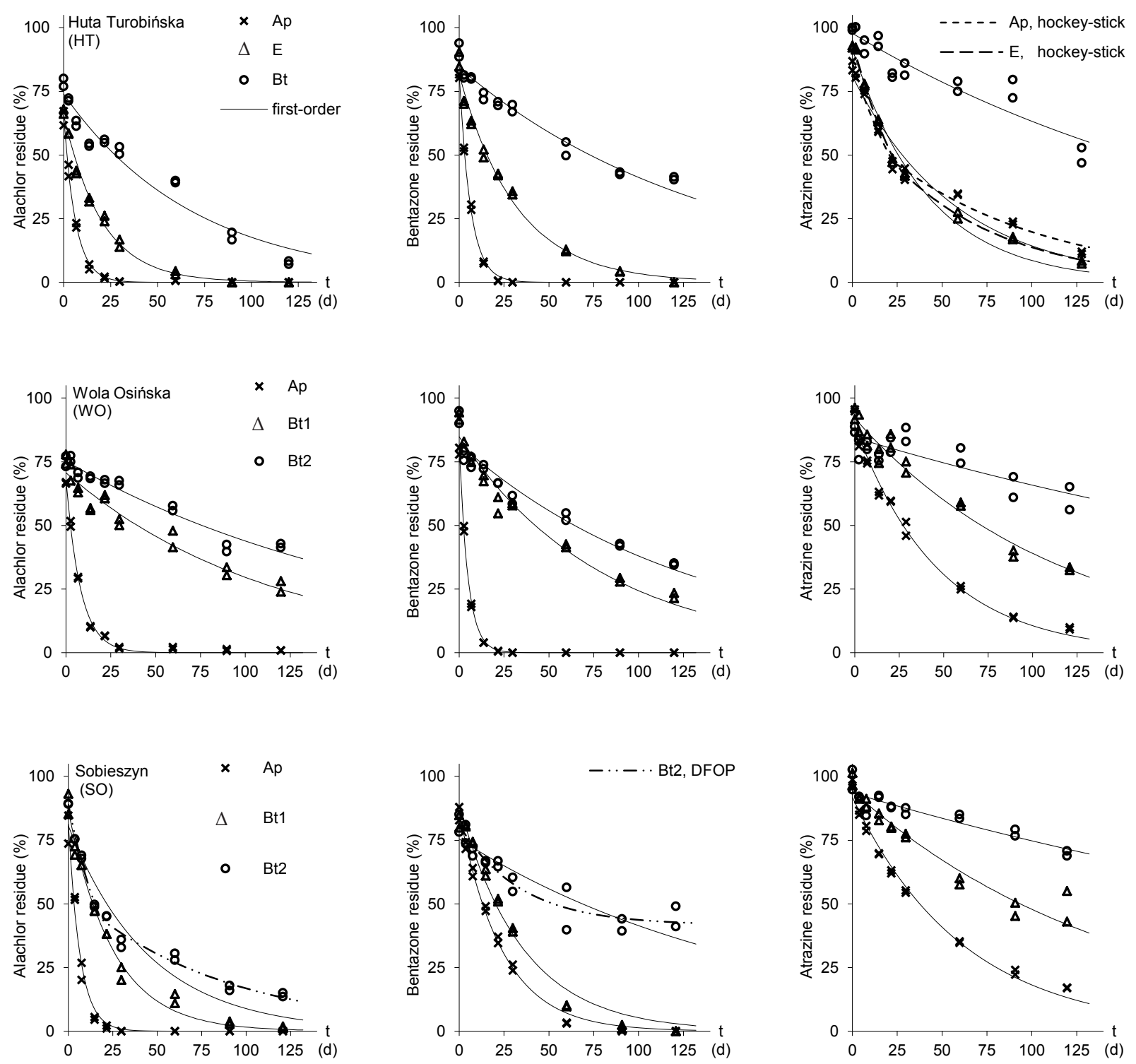

Fig. 2. Fit of first-order, hockey-stick or bi-exponential (DFOP) kinetic models to the degradation data of alachlor, atrazine, bentazone at $25^{\circ} \mathrm{C}$ and $40 \%$ of MWHC in three soil profiles. 
such kinetics could reflect the behaviour of the compound as a primary substrate without inducing major changes in the size of microbial populations (Rodríguez-Cruz et al., 2008). First-order kinetics has been observed previously for alachlor (Rodríguez-Cruz and Lacorte, 2005), bentazone (Ghafoor, 2011a; Li et al., 2008) and atrazine (Fang et al., 2015; Jenks et al., 1998; Li et al., 2008).

In the degradation experiment of atrazine in the HT profile, the hockey-stick model provided the best fit for the data from Ap $\left(\mathrm{r}_{\mathrm{a}}{ }^{2}=0.990, \chi_{\text {error }}^{2}=3.86\right)$ and $\mathrm{E}\left(\mathrm{r}_{\mathrm{a}}^{2}=0.997, \chi_{\text {error }}^{2}\right.$ $=2.49)$ horizons. The hockey-stick model also produced the best results for the degradation of alachlor in the Bt2 horizon of the SO profile $\left(r_{a}^{2}=0.989, \chi_{\text {error }}^{2}=4.29\right)$. In the experiment evaluating the degradation of bentazone in the Bt2 horizon of the SO profile, the best fit $\left(\mathrm{r}_{\mathrm{a}}{ }^{2}=0.890, \chi_{\text {error }}^{2}\right.$ $=5.98)$ was achieved for the DFOP model. The satisfactory results delivered by the two bi-phasic kinetic models could point to a minor decrease in the herbicide concentration in the soil solution due to slow sorption (Pignatello and Xing, 1995), or they could be influenced by the values of the Freundlich coefficient $1 / \mathrm{n}<<1$. However, the examined herbicides are rather weakly adsorbed in soils. Since degradation is not expected to be limited by sorption for compounds with $\mathrm{K}_{\mathrm{OC}}<100 \mathrm{~cm}^{3} \mathrm{~g}^{-1}$ (Ghafoor et al., 2011b), the satisfactory results for the bi-phasic kinetic models are more likely to be associated with decreased activity of soil microorganisms resulting from limited availability of nutrients or carbon at the end of the experiment. However, the values of $\chi_{\text {error }}^{2}$ and $r_{a}^{2}$ did not differ considerably, and the values of rate constant $\mathrm{k}$ and $\mathrm{DT}_{50}$ determined in the firstorder kinetic model (Table 2) were sufficiently consistent with FOCUS (2006) recommendations. Therefore, successive parts of the discussion will be based on the results of first-order kinetics.

The degradation rates of the examined herbicides decreased with an increase in soil depth (Fig. 2, Table 2), which corroborates the findings of other authors (Blume et al., 2004; Rodríguez-Cruz et al., 2008; Shapir and Mandelbaum, 1997; Yen et al., 1994). The activity of soildwelling microorganisms and their ability to degrade pesticides are positively correlated with organic matter content (Ghafoor et al., 2011b; Kah et al., 2007), which decreases with soil depth. This clearly suggests that microbial degradation was the predominant process in our experiment. The only exception was noted for atrazine in the HT profile, where the evaluated compound was degraded at a somewhat faster rate in the E horizon than in the Ap horizon. A comparison of atrazine degradation rates in the Ap horizon indicates that this herbicide was degraded at a similar rate in the HT profile as in the WO and SO profiles. By contrast, atrazine was degraded much faster in the $\mathrm{E}$ horizon than in the Bt1 horizon of the $\mathrm{WO}$ and $\mathrm{SO}$ profiles $\left(\mathrm{DT}_{50}\right.$ values, Table 2). An exception to the rule that the degradation rate decreases with depth was previously reported e.g. by Di et al. (1998).
The average $\mathrm{DT}_{50}$ values for all three herbicides at $25^{\circ} \mathrm{C}$ (Table 2) were determined at $46.5 \mathrm{~d}$ (SE 17.0; SE - standard error) in HT, $73.8 \mathrm{~d}$ (SE 32.1) in SO, and 83.6 d (SE 27.7) in WO profiles. The average $\mathrm{C}_{\mathrm{OC}}$ values were determined at $0.44 \%$ in HT, $0.39 \%$ in SO, and $0.38 \%$ in WO profiles (Table 1 ). These results indicate that the degradation potential is correlated with the organic matter content of soil. The average $\mathrm{DT}_{50}$ value noted in the 9 examined horizons of three soil profiles was lowest for alachlor (37.1 d, SE 14.1), slightly higher for bentazone (47.7 d, SE 14.4), and the highest for atrazine (119.1 d, SE 35.8). Based on the average $\mathrm{DT}_{50}$ values determined in the Ap horizon only, the tested herbicides were arranged in the same order: alachlor $(4.9 \mathrm{~d}, \mathrm{SE}$ $0.4)<$ bentazone ( $8.1 \mathrm{~d}$, SE 4.2$)<$ atrazine (38.5 d, SE 3.0). Identical sequences were previously obtained by Schwab et al. (2006) (alachlor < atrazine) and Li et al. (2008) (bentazone $<$ atrazine). An identical sequence based on $\mathrm{DT}_{50}$ values was also reported by Wauchope et al. (1992): alachlor $(15 \mathrm{~d})<$ bentazone $(20 \mathrm{~d})<$ atrazine $(60 \mathrm{~d})$.

Analyses of Pearson ( $\mathrm{r})$ and Spearman $\left(\rho_{S}\right)$ correlation coefficients (Table 3 ) revealed significant positive correlations between the degradation rates of the examined herbicides and soil $\mathrm{C}_{\mathrm{OC}}$ values $(0.758<\mathrm{r}<0.948 ; 0.767$ $\left.<\rho_{\mathrm{S}}<0.917\right)$. Similar correlations were previously reported by Blume et al. (2004) for atrazine and by Ghafoor et al. (2011a), Rodríguez-Cruz et al. (2006) and (2008) for bentazone.

The results of this study also indicate that in most cases, degradation rates were significantly negatively correlated with clay content $\left(-0.865<\mathrm{r}<-0.582 ;-0.898<\rho_{\mathrm{S}}<-0.746\right)$. Because MWHC was correlated with clay content $(\mathrm{r}=$ $\left.0.860 ; \rho_{\mathrm{S}}=0.814\right)$, the values of Pearson correlation coefficients revealed to a negative correlation between MWHC and the degradation rates of alachlor $(r=-0.702)$ and atrazine $(r=-0.730)$. However, the $r$-values were lower than the values for $\mathrm{C}_{\text {clay }}$ and the $\rho_{\mathrm{S}}$ values were not significant (Table 3). This implies that microbial activity and degradation rates are more likely to be negatively influenced by $\mathrm{C}_{\text {clay }}$ than MWHC. A negative correlation between pesticide degradation rate and clay content was previously reported by Walker (1985) and Allen and Walker (1987). However, in our study, the $\mathrm{C}_{\mathrm{OC}}$ and $\mathrm{C}_{\text {clay }}$ values were highly negatively correlated with each other (Table 3 and Fig. 3), which is typical of Luvisols. The negative correlation between $\mathrm{C}_{\text {clay }}$ and degradation rate could be attributed to multicollinearity resulting from the negative correlation between $\mathrm{C}_{\text {clay }}$ and $\mathrm{C}_{\mathrm{OC}}$.

The relationships between the degradation rates of alachlor, bentazone, and atrazine, and soil properties (Table 1) are presented graphically in the PCA plot in Fig. 3. In twocomponent space (the eigenvalue for the third component was 0.87 ), the first component explained $60.7 \%$ and the second component explained $19.7 \%$ of variance (total of $80.4 \%$ ). The largest positive weights on the first component were noted for $\mathrm{C}_{\mathrm{OC}}(\mathrm{C} 10.39, \mathrm{C} 20.04)$ and the first-order 


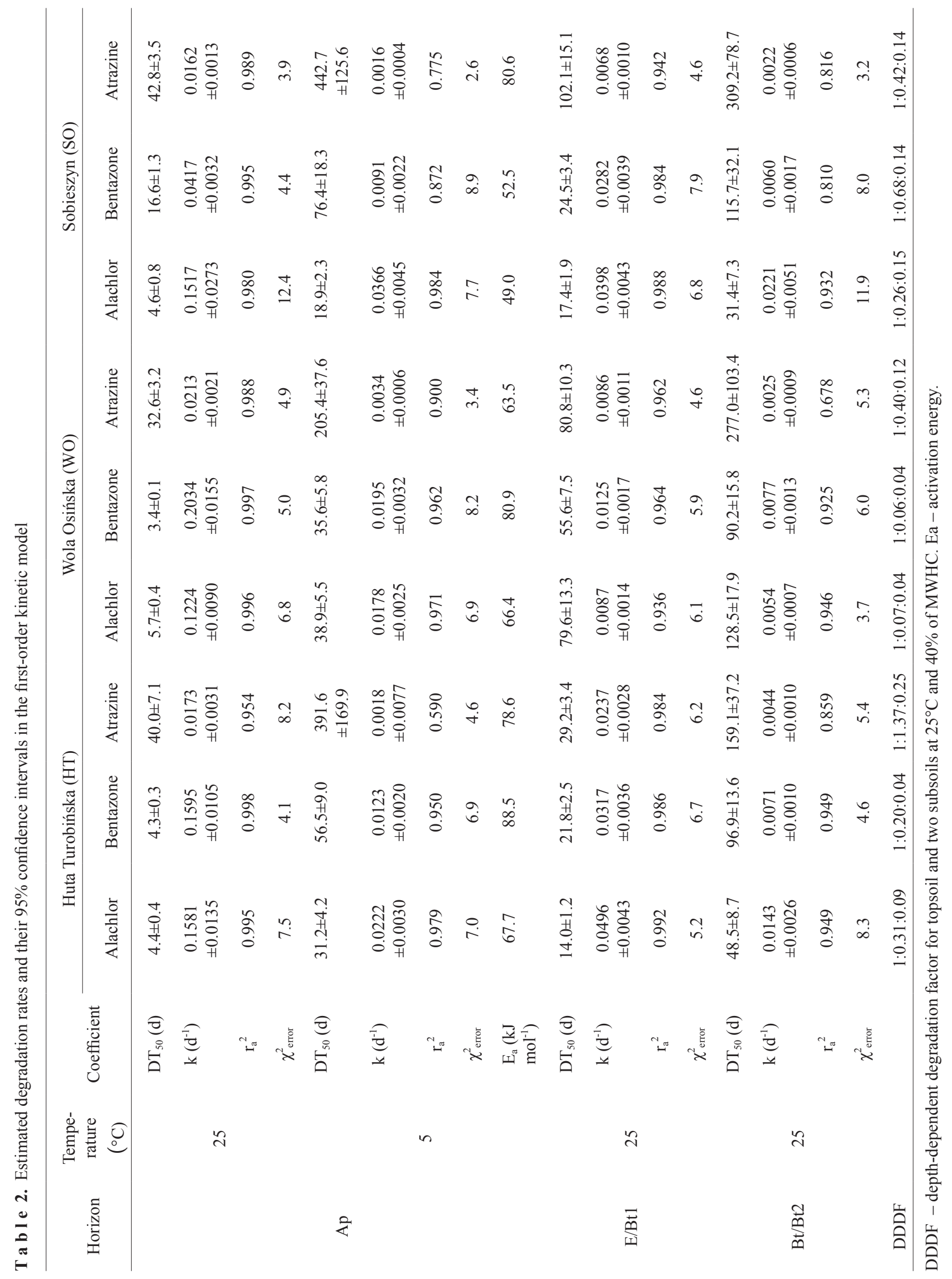


T a b l e 3. Values of Pearson correlation coefficient (left side), Spearman rank correlation coefficient (right side) and their p-values (subscript brackets) for relationships between soil properties and degradation rates $(n=9)$

\begin{tabular}{lllllllllll}
\hline & $\mathrm{k}_{\text {Ala }}$ & $\mathrm{k}_{\text {Ben }}$ & $\mathrm{k}_{\text {Atr }}$ & Depth & $\mathrm{pH}$ & $\mathrm{C}_{\mathrm{OC}}$ & $\mathrm{C}_{\text {sand }}$ & $\mathrm{C}_{\text {silt }}$ & $\mathrm{C}_{\text {clay }}$ & MWHC \\
\hline $\mathrm{k}_{\text {Ala }}$ & & 0.800 & 0.683 & -0.912 & 0.672 & 0.850 & 0.200 & 0.711 & -0.797 & -0.650 \\
& & $(0.024)$ & $(0.053)$ & $(0.010)$ & $(0.057)$ & $(0.016)$ & $(0.572)$ & $(0.044)$ & $(0.024)$ & $(0.066)$ \\
$\mathrm{k}_{\text {Ben }}$ & 0.757 & & 0.867 & -0.895 & 0.244 & 0.917 & 0.400 & 0.427 & -0.746 & -0.650 \\
& $(0.018)$ & & $(0.014)$ & $(0.011)$ & $(0.491)$ & $(0.009)$ & $(0.258)$ & $(0.227)$ & $(0.035)$ & $(0.066)$ \\
$\mathrm{k}_{\text {Atr }}$ & 0.698 & 0.654 & & -0.761 & 0.092 & 0.767 & 0.167 & 0.594 & -0.898 & -0.667 \\
& $(0.037)$ & $(0.056)$ & & $(0.031)$ & $(0.794)$ & $(0.030)$ & $(0.637)$ & $(0.093)$ & $(0.011)$ & $(0.059)$ \\
Depth & -0.850 & -0.683 & -0.806 & & -0.582 & -0.979 & -0.402 & -0.487 & 0.715 & 0.527 \\
& $(0.004)$ & $(0.043)$ & $(0.009)$ & & $(0.010)$ & $(0.006)$ & $(0.256)$ & $(0.168)$ & $(0.043)$ & $(0.136)$ \\
$\mathrm{pH}$ & 0.600 & 0.195 & 0.240 & -0.601 & & 0.487 & 0.395 & 0.266 & -0.291 & -0.244 \\
& $(0.088)$ & $(0.615)$ & $(0.534)$ & $(0.087)$ & & $(0.168)$ & $(0.264)$ & $(0.452)$ & $(0.411)$ & $(0.491)$ \\
$\mathrm{C}_{\mathrm{OC}}$ & 0.948 & 0.758 & 0.860 & -0.932 & 0.484 & & 0.433 & 0.410 & -0.695 & -0.533 \\
& $(<0.001)$ & $(0.018)$ & $(0.003)$ & $(0.003)$ & $(0.187)$ & & $(0.220)$ & $(0.246)$ & $(0.049)$ & $(0.131)$ \\
$\mathrm{C}_{\text {sand }}$ & 0.275 & 0.254 & 0.186 & -0.492 & 0.399 & 0.357 & & -0.443 & 0.000 & -0.250 \\
& $(0.473)$ & $(0.509)$ & $(0.632)$ & $(0.178)$ & $(0.288)$ & $(0.346)$ & & $(0.210)$ & $(1.000)$ & $(0.479)$ \\
$\mathrm{C}_{\text {silt }}$ & 0.302 & 0.203 & 0.455 & -0.117 & -0.004 & 0.270 & -0.721 & & -0.826 & -0.611 \\
& $(0.430)$ & $(0.601)$ & $(0.219)$ & $(0.764)$ & $(0.992)$ & $(0.482)$ & $(0.028)$ & & $(0.019)$ & $(0.084)$ \\
$\mathrm{C}_{\text {clay }}$ & -0.748 & -0.582 & -0.865 & 0.731 & -0.450 & -0.795 & -0.106 & 0.612 & & 0.814 \\
& $(0.020)$ & $(0.100)$ & $(0.003)$ & $(0.002)$ & $(0.225)$ & $(0.010)$ & $(0.786)$ & $(0.080)$ & & $(0.021)$ \\
MWHC & -0.702 & -0.569 & -0.730 & 0.669 & -0.308 & -0.755 & -0.328 & -0.338 & 0.860 & \\
& $(0.035)$ & $(0.110)$ & $(0.025)$ & $(0.049)$ & $(0.420)$ & $(0.019)$ & $(0.389)$ & $(0.373)$ & $(0.003)$ & \\
\hline
\end{tabular}

Depth - correlations based on average depth in the examined horizons (Table 1).

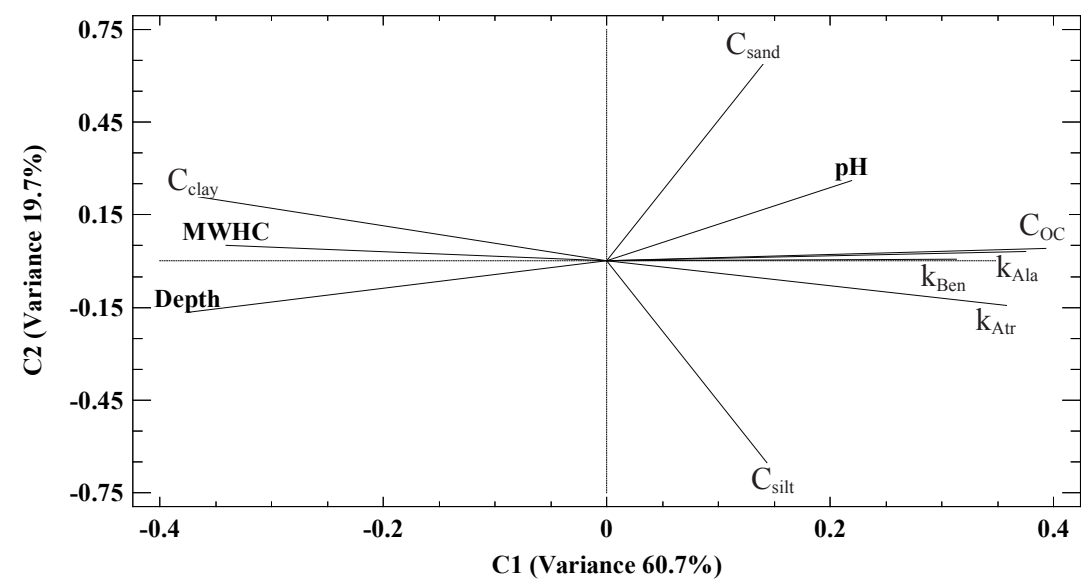

Fig. 3. PCA analysis of the relationships between first-order degradation rate constants of alachlor $\left(\mathrm{k}_{\mathrm{Ala}}\right)$, atrazine $\left(\mathrm{k}_{\mathrm{Atr}}\right)$, bentazone $\left(\mathrm{k}_{\mathrm{Ben}}\right)$ and soil properties.

degradation rate coefficients for alachlor (C1 0.37, C2 0.03 ), atrazine ( $\mathrm{C} 10.36, \mathrm{C} 2-0.14)$, and bentazone ( $\mathrm{C} 1$ $0.31, \mathrm{C} 20.01$ ). The above variables are located on the right side in Fig. 3, and they are highly positively correlated with each other (Table 3 ). The smallest negative weights on the first component were observed for $\mathrm{C}_{\text {clay }}(\mathrm{C} 1-0.37, \mathrm{C} 20.21)$, average sampling depth (C1 -0.37, C2 -0.17), and MWHC (C1 -0.34, C2 0.05). These variables are located on the left side in Fig. 3, and they are highly negatively correlated with degradation rates and $\mathrm{C}_{\mathrm{OC}}$ and positively correlated with each other (Table 3).
The largest weight on the second component was determined for $\mathrm{C}_{\text {sand }}(\mathrm{C} 10.14, \mathrm{C} 20.64)$ and the smallest weight was noted for $\mathrm{C}_{\text {silt }}(\mathrm{C} 10.14, \mathrm{C} 2-0.65)$. These two variables, located on the opposing sides in Fig. 3, are negatively correlated with each other and are not correlated with $\mathrm{C}_{\mathrm{OC}}$ or first-order degradation rate coefficients of the examined herbicides (Table 3). Thus, both PCA and correlation analysis suggest that neither of the two variables affects degradation. The small weights for $\mathrm{pH}(\mathrm{C} 10.22, \mathrm{C} 20.26)$ also indicate that this variable is less important in terms of its effect on degradation rates. Interestingly, the values of both Pearson and Spearman correlation coefficients indicate 
that degradation rate and $\mathrm{pH}$ are bound by positive but not significant correlations. Near-neutral $\mathrm{pH}$ contributes to biomass growth because bacterial populations in acidic soils decrease in response to the adverse effects of exchangeable $\mathrm{Al}$ (Moreale and van Bladel, 1980). However, only some soil microorganisms can utilize pesticides as sources of carbon and energy. The rate at which pesticides are degraded by microbes is influenced by $\mathrm{pH}$ only indirectly; therefore, the effect of $\mathrm{pH}$ may be low.

The values of $\mathrm{E}_{\mathrm{a}}$ calculated from the Arrhenius equation based on the results of degradation experiments carried out in the Ap horizon at 5 and $25^{\circ} \mathrm{C}$ are presented in Table 2. The values obtained for alachlor $\left(49.0-67.7 \mathrm{~kJ} \mathrm{~mol}^{-1}\right.$, average of $61.0 \mathrm{~kJ} \mathrm{~mol}^{-1}$ ) are in the lower range of the 7 values $\left(56.9-80.7 \mathrm{~kJ} \mathrm{~mol}^{-1}\right.$, average of $\left.71.9 \mathrm{~kJ} \mathrm{~mol}^{-1}\right)$ obtained in previous studies (EFSA, 2008). The values obtained for atrazine $\left(63.5-80.6 \mathrm{~kJ} \mathrm{~mol}^{-1}\right.$, average of $\left.74.2 \mathrm{~kJ} \mathrm{~mol}^{-1}\right)$ are in the upper range of the 7 values $\left(45.1-83.7 \mathrm{~kJ} \mathrm{~mol}^{-1}\right.$, average of $48.3 \mathrm{~kJ} \mathrm{~mol}^{-1}$ ) listed by EFSA (2008). To the best of our knowledge, only two $E_{a}$ values for bentazone are available in the literature: the value of $74.7 \mathrm{~kJ} \mathrm{~mol}^{-1}$ obtained by Scorza et al. (2004), which is close to our results (52.5$88.5 \mathrm{~kJ} \mathrm{~mol}^{-1}$, average of $74.0 \mathrm{~kJ} \mathrm{~mol}^{-1}$ ), and the extremely high value of $113.3 \mathrm{~kJ} \mathrm{~mol}^{-1}$ obtained by Boesten and van der Pas (2000). Given the variability of the above results (see also the $\mathrm{E}_{\mathrm{a}}$ values for MCPA in Paszko (2009) and for carbendazim in Paszko and Skrzypek (2010)), a default value of $68.9 \mathrm{~kJ} \mathrm{~mol}^{-1}$, which is recommended for pesticides by EFSA (2008), should give correct results for the relationship between temperature and pesticide degradation rates in Polish soils.

The main aim of this study was to determine the depthdependent degradation factor (DDDF) for the examined soils. The DDDF value for horizon X in the soil profile was calculated with the use of the following formula: $\operatorname{DDDF}(\mathrm{X})$ $=\mathrm{k}(\mathrm{X}) / \mathrm{k}(\mathrm{Ap})$, where $\mathrm{k}$ is the first-order rate constant. High variability of DDDF can be observed in the upper subsoil horizon (E or Bt1, sampling depth of 25-50 cm) (Table 2). The arithmetic mean of 9 values is 0.42 (SD 0.40; SD standard deviation). This could be attributed to the fact that the degradation rate of atrazine in the upper subsoil horizon of HT was $37 \%$ higher than in the topsoil, and the degradation rates of alachlor and bentazone in WO decreased to $6-7 \%$ of the rates in topsoil. Such high variability could partially result from the minor differences in sampling depth (Table 1). Highly variable degradation rates are typical of subsoils, as demonstrated by Rodríguez-Cruz et al. (2006). The average value of DDDF for lower subsoil horizons (Bt and Bt2, sampling depth of 55-90 cm) was 0.11 (SD 0.07). In this soil horizon, the variability of DDDF was lower despite the greater differences in sampling depth. This can probably be attributed to the low variability of organic matter content $\left(\mathrm{C}_{\mathrm{OC}} 0.04-0.12 \%\right)$ and microbial biomass in this horizon.
The results of one-way ANOVA, performed separately for two subsoils, did not reveal significant differences in DDDF values for the examined herbicides at the probability level of $95 \%$. Therefore, it can be concluded that DDDF values are soil-specific and are dependent mainly on soil properties. According to Kördel et al. (1995), microbial populations are similar across soil horizons due to the migration of soil-dwelling microorganisms from topsoil to subsoils and microbial exchange between horizons. Similar microbial patterns should lead to similar pesticide degradation patterns throughout the soil profile. These observations suggest that averaged results should be used to reliably estimate DDDF values for subsoils in the examined soil type.

The DDDF values for the three examined horizons (sampling depth of: 5-20, 25-50, and 55-90 cm), were 1: 0.31: 0.12 based on median values and 1: 0.42 : 0.11 based on average values. Median values seem to better reflect typical values because the arithmetic average accounts for outliers. Organic matter is a surrogate indicator of microbial activity; therefore, DDDF values were also determined based on the $\mathrm{C}_{\mathrm{OC}}$ values of different soil horizons $\left(\operatorname{DDDF}(\mathrm{X})=\mathrm{C}_{\mathrm{OC}}(\mathrm{X}) / \mathrm{C}_{\mathrm{OC}}(\mathrm{Ap})\right)$. The calculated values of 1 : 0.45: 0.12 were almost identical to the values determined based on arithmetic means $(r=0.999, p=0.016)$. However, Rodríguez-Cruz et al. (2008) did not report such a strict relationship between DDDF and $\mathrm{C}_{\mathrm{OC}}$ in a study of bentazone degradation.

The results of our study are within the range of values previously noted in Polish soils. The calculated DDDF values for carbendazim degradation in Luvisols developed in loess-like formations (with properties similar to those of HT samples) were 1: 0.61: 0.16: 0.07 for $A p(5-15 \mathrm{~cm})$, Eg $(25-35 \mathrm{~cm})$, Bt $(50-60 \mathrm{~cm})$ and $2 \mathrm{C}_{\mathrm{ca}}(80-90 \mathrm{~cm})$ horizons (Paszko and Skrzypek, 2010). The values for the Eg and $\mathrm{Bt}$ horizons were higher than the above average values because Paszko and Skrzypek (2010) collected soil samples at a lower depth. Paszko (2009) and (2014) also analysed carbendazim and MCPA degradation in a Luvisol profile (Ap, E and Bt horizons; sampling depth of 5-15, 35-45, and $65-75 \mathrm{~cm}$, respectively). Taking into account the $\mathrm{DT}_{50}$ values at $25^{\circ} \mathrm{C}$, the values of DDDF were 1: 0.46: 0.08 for carbendazim and 1: $0.17: 0.05$ for MCPA, and they were within the range obtained in the present study.

Rodríguez-Cruz et al. (2008) analysed bentazone degradation in three profiles of Wick series soil from the United Kingdom. Their results indicated that DDDF values decreased in the order of 1: 0.86 : $0.31: 0.18$ : and 0.11 for sampling depths of 0-10, 20-30, 40-50, 60-70, and 70-80 cm, respectively. The results noted for sampling depths of 40-50, $60-70$, and $70-80 \mathrm{~cm}$ are consistent with our findings. Our results are also similar to those reported by Rodríguez-Cruz et al. (2006) in the same soil. The values obtained for 20 topsoil $(0-15 \mathrm{~cm})$ and subsoil $(50-60 \mathrm{~cm})$ samples of Wick soil were 1: 0.28 for bentazone, $1: 0.07$ for isoproturon, and 1: 0.35 for mecoprop-p. 
The default values of DDDF proposed by FOCUS (2014) for Tier 1 calculations of pesticide translocation into groundwater using pesticide-leaching models are 1: 0.5 : 0.3 for sampling depths of $0-30,30-60$, and $60-100 \mathrm{~cm}$, respectively. Our findings indicate that the DDDF values for subsoils ( 0.5 and 0.3$)$ will lead to the underestimation of pesticide translocation to groundwater in some Polish soils. The calculated median values are more reliable indicators of the degradation potential of subsoils for Polish Luvisols and the respective horizons of Wick series soils (Rodríguez- Cruz et al., 2006, 2008).

\section{CONCLUSIONS}

1. The degradation potential of the three examined soil profiles (Huta Turobińska $>$ Sobieszyn $>$ Wola Osińska) corresponded to the decreasing order of the average content of organic carbon in the profiles. The values of depthdependent degradation factor are more soil-specific than substance-specific; therefore, the average depth-dependent degradation factor values for the examined herbicides for topsoil and two subsoils (1: 0.42: 0.11 ) were almost identical to the depth-dependent degradation factor values determined based on organic matter content (1: 0.45: 0.12). Based on the average degradation rates for both topsoil and subsoils, the analysed pesticides were arranged in the following order: alachlor $>$ bentazone $>$ atrazine, which indicates that degradation rates in individual horizons are substance-specific.

2. The values of depth-dependent degradation factor obtained for topsoil and two subsoil horizons (1: 0.42: 0.11 - based on average values and 1: 0.31: 0.12 - based on median values) reflect the degradation potential of subsoils in Polish Luvisols. The values of depth-dependent degradation factor are soil-specific; therefore, they can also be used to examine other pesticides in this soil group. However, subsoil degradation rates are highly varied, and further research is needed to validate this finding. The results of this study indicate that soil degradation behaviour can be estimated reliably and relatively easily based on determination of typical depth-dependent degradation factor values for subsoils of soil groups used mostly in agriculture.

Conflict of interest: The Authors do not declare conflict of interest.

\section{REFERENCES}

Allen R. and Walker A., 1987. The influence of soil properties on the rates of degradation of metamitron, metazachlor and metribuzin. Pestic. Sci., 18(2), 95-111.

Bieganowski A., Witkowska-Walczak B., Gliński J., Sokołowska Z., Sławiński C., Brzezińska M., and Włodarczyk T., 2013. Database of Polish arable mineral soils: a review. Int. Agrophys., 27, 335-350.

Blume E., Bischoff M., Moorman T.B., and Turco R.F., 2004. Degradation and binding of atrazine in surface and subsurface soils. J. Agric. Food Chem., 52, 7382-7388.
Boesten J.J.T.I. and van der Pas L.J.T., 2000. Movement of water, bromide ion and the pesticides ethoprophos and bentazone in a sandy soil: the Vredepeel data set. Agric. Water Manag., 44, 21-42.

Chou S.H., 1977. Fate of acylanilides in soils and polybrominated biphenyls (PBBs) in soils and plants. Ph.D. Dissertation, Michigan State University, East Lansing, MI, USA.

Dehghani M., Nasseri S., and Zamanian Z., 2013. Biodegradation of alachlor in liquid and soil cultures under variable carbon and nitrogensources by bacterial consortium isolated from corn field soil. J. Environ. Health Sci. Eng., 10, 21,1-10. doi:10.1186/1735-2746-10-21, http://www.ijehse. com/content/10/1/21.

Di H.J., Aylmore L.A.G., and Kookana R.S., 1998. Degradation rates of eight pesticides in surface and subsurface soils under laboratory and field conditions. Soil Sci., 163, 404-411.

EFSA, 2008. Scientific opinion of the panel on plant protection products and their residues on a request from EFSA related to the default Q10 value used to describe the temperature effect on transformation rates of pesticides in soil. EFSA J., 622, 1-32, http://onlinelibrary.wiley.com/doi/10.2903/j.efsa. 2008.622/full

EU pesticide database, 2016. http://ec.europa.eu/food/plant/pesticides/eu-pesticides-database/public/?event=active substance.detail\&language $=\mathrm{EN} \&$ selectedID $=1014$

European Commission, 2014. Assessing potential for movement of active substances and their metabolites to ground water in the EU Report of the FOCUS Ground Water Work Group, EC Document Reference Sanco/13144/2010 ver. 3.

Fang C.H., 1979. Studies on the degradation and dissipation of herbicide alachlor on soil thin layers (in Chinese). J. Chinese Agric. Chem. Soc., 17, 47-53.

Fang H., Lian J., Wang H., Cai L., and Yu Y., 2015. Exploring bacterial community structure and function associated with atrazine biodegradation in repeatedly treated soils. J. Hazard. Mater., 286, 457-465.

FOCUS, 2006. Guidance document on estimating persistence and degradation kinetics from environmental fate studies on pesticides in EU registration Report of the FOCUS Work Group on Degradation Kinetics, EC Document Reference Sanco/10058/2005 ver. 2.0. http://esdac.jrc.ec.europa.eu/ public_path/projects_data/focus/dk/docs/ FOCUSkineticsvc1.1Dec2014.pdf

FOCUS, 2014. Generic guidance for Tier 1 FOCUS ground water assessments. Version 2.2, http://esdac.jrc.ec.europa.eu/public_path/projects_data/focus/gw/NewDocs/Generic Guidance2_2.pdf

Ghafoor A., Jarvis N.J., Thierfelder T., and Stenström J., 2011a. Measurements and modeling of pesticide persistence in soil at the catchment scale. Sci. Total Environ., 409, 1900-1908.

Ghafoor A., Moeys J., Stenström J., Tranter G., and Jarvis N.J., 2011b. Modeling spatial variation in microbial degradation of pesticides in soil. Environ. Sci. Technol., 45, 6411-6419.

Goberna M., Sanchez J., Pascual J.A., and Garcia C., 2006. Surface and subsurface organic carbon, microbial biomass and activity in a forest soil sequence. Soil Biol. Biochem., $38,2233-2243$. 
Huber R. and Otto S., 1994. Environmental behavior of bentazon herbicide. Rev. Environ. Contam. Toxicol., 137, 111-134.

IUSS Working Group WRB, 2015. World reference base for soil resources 2014, update 2015. International soil classification system for naming soils and creating legends for soil maps. World Soil Resources Reports No. 106. FAO, Rome.

Jenks B.M., Roeth F.W., Martin A.R., and McCallister D.L., 1998. Influence of surface and subsurface soil properties on atrazine sorption and degradation. Weed Sci., 46(1), 132-138.

Kah M., Beulke S., and Brown C.D., 2007. Factors influencing degradation of pesticides in soil. J. Agric. Food Chem., 55, 4487-4492.

Karpouzas D.G., Walker A., Drennan D.S.H., and FroudWilliams R.J., 2001. The effect of initial concentration of carbofuran on the development and stability of its enhanced biodegradation in top-soil and sub-soil. Pest Manag. Sci., $57,72-81$.

Kördel W., Wahle U., Knoche H., and Hund K., 1995. Degradation capacities of chlorotoluron and simazine in subsoil horizons. Sci. Total Environ., 1-3, 43-50.

Li K.B., Cheng J.T., Wang X.F., Zhou Y., and Liu W.P., 2008. Degradation of herbicides atrazine and bentazone applied alone and in combination in soils. Pedosphere, 18(2), 265-272.

Moreale A. and van Bladel R., 1980. Behavior of 2,4-D in Belgian soils. J. Environ. Qual., 9, 627-633.

Norgaard T., de Jonge L.W., Moldrup P., Olsen P., and Johnsen A.R., 2015. Can simple soil parameters explain field-scale variations in glyphosate-, bromoxyniloctanoate-, diflufenican-, and bentazone mineralization? Water Air Soil Pollut., 226(262), 1-13.

NPIC, 2016. (National Pesticide Information Center) Pesticide Products: NPRO: Pesticide Product Search, http://npic.orst. edu

OECD, 2002. OECD guideline for the testing of chemicals. Method 307. Aerobic and anaerobic transformation in soil. OECD, Paris, France.

Paszko T., 2009. Degradation of MCPA in soil horizons of Polish agricultural soils. Pol. J. Environ. Stud., 18(6), 1083-1091.

Paszko T., 2014. Adsorption, degradation and mobility of carbendazim in profiles of Polish mineral soils. Geoderma, 226-227, 160-169.

Paszko T. and Skrzypek A., 2010. Adsorption, desorption and degradation of carbendazim in the loess-like soil. Ecolog. Chem. Engineer. A, 17(2-3), 249-259.

Pignatello J.J. and Xing B., 1995. Mechanisms of slow sorption of organic chemicals to natural particles. Environ. Sci. Technol., 30(1), 1-11.

PPDB (Pesticide Properties Database), 2016. http://www.herts. ac.uk/aeru/footprint
Rodríguez-Cruz M.S., Jones J.E., and Bending G.D., 2006. Field-scale study of the variability in pesticide biodegradation with soil depth and its relationship with soil characteristics. Soil Biol. Biochem., 38, 2910-2918.

Rodríguez-Cruz M.S., Jones J.E., and Bending G.D., 2008. Study of the spatial variation of the biodegradation rate of the herbicide bentazone with soil depth using contrasting incubation methods. Chemosphere, 73, 1211-1215.

Rodríguez-Cruz M.S. and Lacorte S., 2005. Degradation of alachlor in natural and sludge amended soils, studied by gas and liquid chromatography coupled to mass spectrometry (GC-MS and HPLC-MS). J. Agric. Food Chem., 53(24), 9571-9577.

Schmidt S.K., Simkins S., and Alexander M., 1985. Models for the kinetics of biodegradation of organic compounds not supporting growth. Appl. Environ. Microbiol., 50, 323-331.

Schwab A.P., Spichal P.A., and Banks M.K., 2006. Persistence of atrazine and alachlor in ground water aquifers and soil. Water Air Soil Pollut., 171(1), 203-235.

Scorza Júnior R.P., Smelt J.H., Boesten J.J.T.I., Hendriks R.F.A., and van der Zee S.E.A.T.M., 2004. Preferential flow of bromide, bentazon, and imidacloprid in a Dutch clay soil. J. Environ. Qual., 33, 1473-1486.

Shapir N. and Mandelbaum R.T., 1997. Atrazine degradation in subsurface soil by indigenous and introduced microorganisms. J. Agric. Food Chem., 45, 4481-4486.

Spalding R.F., Exner M.E., Snow D.D., Casada D.A., Burbach M.E., and Monson S.J., 2003. Herbicides in ground water beneath Nebraska's management systems evaluation area. J. Environ. Qual., 32, 92-99.

Tomlin C.D.S., 2006. The Pesticide Manual. The British Crop Protection Council, Alton, Hampshire, UK.

Vinther F.P., Brinch U.C., Elsgaard L., Fredslund L., Iversen B.V., Torp S., and Jacobsen C.S., 2008. Field-scale variation in microbial activity and soil properties in relation to mineralization and sorption of pesticides in a sandy soil. J. Environ. Qual., 37, 1710-1718.

Vryzas Z., Papadakis E.N., and Mourkidou P., 2012. Leaching of Br-, metachlor, alachlor, atrazine, deethylatrazine and deisopropylatrazine in clayey vadoze zone: a field scale experiment in North-East Greece. Water Res., 46(6), 1979-1989.

Walker A. and Brown P.A., 1985. The relative persistence in soil of five acetanilide herbicides. Bull. Environ. Contam. Toxicol., 34, 143-149.

Wauchope R.D., Buttler T.M., Hornsby A.G., Augustijnbeckers P.W.M., and Burt J.P., 1992. The SCS/ARS/CES pesticide properties database for environmental decision-making. In: Reviews of Environmental Contamination and Toxicology, (Eds G.W. Ware). Springer-Verlag, New York, USA.

Yen P.Y., Koskinen W.C., and Schweizer E.E., 1994. Dissipation of alachlor in four soils as influenced by degradation and sorption processes. Weed Sci., 42(2), 233-240. 